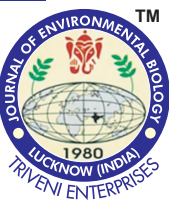

\title{
Production of activated carbon from mango seed coat using chemical activation
}

\begin{tabular}{lll}
\hline Paper received: 23.08.2017 & Revised received: 23.02.2018 Re-revised received:02.05.2018 Accepted: 25.12 .2018 \\
\hline
\end{tabular}

\section{Authors Info \\ B. Vijayakumar ${ }^{1 *}$, M. Arulmozhi', B.G. Prakash Kumar ${ }^{3}$ and G. Ashwin ${ }^{4}$ \\ 'Department of Petrochemical Technology, Excel College of Engineering and Technology, Komarapalayam - 637303 , India \\ ${ }^{2}$ Department of Petrochemical Technology, BIT Campus, \\ Anna University, \\ Tiruchirappalli-620 024, India \\ ${ }^{3}$ Department of Chemical Engineering, Birla Institute Of Technology and Science Pilani, Dubai-345 055, UAE \\ ${ }^{4}$ Department of Chemical Engineering, Erode Sengunther Engineering College, Erode-638 057, India}

*Corresponding Author Email : vijaikumar143@gmail.com

\section{Edited by \\ Dr. Bharati Pal}

Reviewed by

Dr. M. Ramya

Dr. R.B. Raizada

\section{Abstract}

Aim : This study was carried out find the feasibility of utilizing raw mango seed coat under various process conditions to produce the best activated carbon by chemical activation and compared with commercial activated carbon.

Methodology : Activated carbon was produced by chemical activation under various process conditions such as different activation temperatures, activating agents, impregnation volume percentages and activation times for pyrolysis in a programmable electrical furnace with reactor in the absence of air.

Results : The results were compared using phosphoric acid having $50 \%$ impregnation volume to other activating agents, the activating temperature was $400^{\circ} \mathrm{C}$, activation time $1 \mathrm{hr}$, iodine number, methylene blue number, $\%$ yield and B.E.T surface area being $831 \mathrm{mg} \mathrm{g}^{-1}, 212 \mathrm{mg} \mathrm{g}^{-1}$, $41.09 \%$ and $1114 \mathrm{~m}^{2} \mathrm{~g}^{-}$ respectively.

Interpretation: Carbon samples prepared using mango seed coat treated by $\mathrm{H}_{3} \mathrm{PO}_{4}$, showed clear
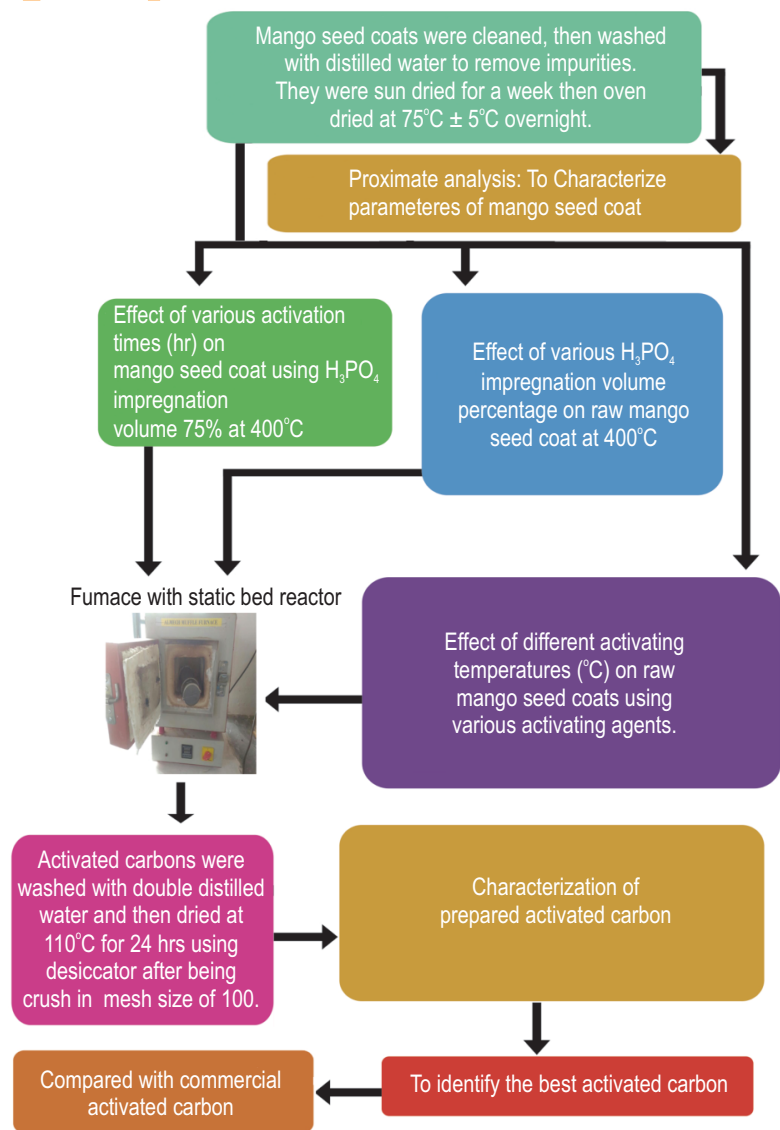
open porous structures along with a larger pore size compared to commercially available activated carbon.

Key words: Activated carbon, B.E.T. surface area, lodine number, Mango seed coat, Methylene blue number

How to cite: Vijayakumar, B.V., M. Arulmozhi, B.G. Prakash Kumar and G. Ashwin : Production of activated carbon from mango seed coat using chemical activation. J. Environ. Biol., 40, 283-290 (2019). 


\section{Introduction}

Activated carbon is a well-known versatile product used for many applications. It is used to remove pollutants from gases and liquids and for purification in several industrial processes. Micro pollutants generally enter water through discharge from various processes including food, dye, textile, paper, plastic chemical and petrochemical industries. The presence of organic pollutants in water has attracted much attention in recent decades because of their potential mutagenicity, carcinogenicity and toxicity. Moreover, it leads to undesirable effects on color, odor and taste of drinking water. It has been demonstrated that conventional treatment processes are ineffective in removing micro pollutants. Fluoride contaminated ground water exceeds the limits, creating natural and anthropogenic activities (Koshle et al., 2016). India is among the 23 nations of the world, where fluoride contaminated ground water is creating health problems. 62 million people including 6 million children in 18 Indian states are affected. Activated carbon exhibits good capacity for removal of fluorine from drinking water (Kumar et al., 2008).

Colored wastewater is a consequence of batch processes both in the dye manufacturing and dye consuming industries. $2 \%$ of dyes produced is discharged directly as aqueous effluent and $10 \%$ is subsequently lost during textile coloration process. An indication regarding the scale of problem is given by the observation that the annual market for dyes is more than 7 X105 tons per year (Pearce et al., 2003). The removal of color from effluents is one of the major environmental problems. Decolorization of wastewater has become one of the major issues in the waste water industry (Saravanan and Rathika, 2018). Activated carbon has been suggested to remove various pollutants from aqueous solutions (Shahmoradi et al., 2015).

Activated carbon is widely used in many fields and can be produced from a variety of carbonaceous materials. Various materials are used to produce activated carbon, some of the most commonly used ones being agricultural wastes such as. Mango pit (Elizalde-Gonzalez and Henandez-Montoya, 2007), Mango seed (Moreno-Pirajan and Giraldo, 2012), Mango seed kernel (Pandharipade et al., 2012), Mango seed shell (Mise and Jagannath, 2013), Palm kernel shell (Abechi et al., 2013), Delonixregia plant litters (Daniel et al., 2015), Sal seeds (Sing et al., 2017) and Coconut shell (Regunton et al., 2017). There are two basic methods for producing activated carbon which include physical and chemical activations (Dubey et al., 2009). Chemical methods are more advantageous than the physical process. Therefore, chemical activation has been selected for the present study.

Mango, one the most important tropical fruits of the world, is usually found in Southern Asia, especially in Eastern India. In India, mango occupies $42.6 \%$ of the total area under food category, comprising 0.94 million ha with a total production of 8.21 million tons from various states. Besides, India is by far the largest producer of mangoes, accounting for $66.2 \%$ of the world production. There are nearly 1060 mango varieties in India.
However, only about 20 of them are grown on commercial scale (Kostermans et al., 1993). The mango pulp industry, while processing mangoes, generates by-products such as peels, kernels (Kittiphoom, 2012) and seed coats, thus producing a large amount of bio-waste. Mango production in India is large, only a small amount is utilized by traditional food industries and the rest is used as raw material for mango pulp industries. In the present study, mango seed coat, which is the bio waste products, of mango was used as a raw precursor for preparing activated carbon. Mango seeds produce a large amount of solid waste. To enhance the value of this bio waste, preparation of activated carbon has been attempted through it. Thus producing activated carbon from mango seed coat not only helps in terms of waste minimization but also helps in reduction of pollution.

Mango seed coat is a lignocellulosic material with hemicellulose, cellulose and lignin as the main components. The present study was carried out to investigate activated carbon prepared from mango seed coat by varying different conditions such as activation temperatures, activating agents, impregnation volume percentages and activation hours. Characteristics such as iodine number, methylene blue number, methyl violet number, percentage yield and Brunauer-Emmett -Teller surface area for various techniques were also measured to identify the quality of activated carbon produced and later compared with commercially available activated carbon.

\section{Materials and Methods}

Preparation of mango seed coat activated carbon: Mango seeds were collected from mango pulp industry located in Dharmapuri, Tamil Nadu, India. First, they were separated into seeds and seed coats followed by removal of unwanted fibers from the seed coats and then washed several times with distilled water to remove impurities. In the next step, they were sun-dried for a week and then oven dried at $75^{\circ} \mathrm{C} \pm 5^{\circ} \mathrm{C}$ overnight. Proximate analysis (Lakshmi et al., 2018) of mango seed coat (wet basis). was carried out next which indicated the following parameters: moisture content $(2.94 \%)$, volatile matter (82.26\%), fixed carbon (14.19\%), ash content $(0.61 \%)$ and sulphur $(0.098 \%)$. After that, they were shredded into small pieces for easy impregnation. Finally, mango seed coat activated carbon was obtained by chemical activation method usingvarying process conditions. Different activating agents (Hagemann et al., 2018) like $\mathrm{HNO}_{3}, \mathrm{H}_{3} \mathrm{PO}_{4}, \mathrm{KOH}, \mathrm{HCl}$, $\mathrm{ZnCl}_{2}, \mathrm{NaOH}$, all at $1 \mathrm{~N}$ were employed. Impregnation volume percentages used were $25 \%$ ( $25 \mathrm{ml}$ of activating agent and $75 \mathrm{ml}$ of water per $100 \mathrm{ml}$ aqueous solution), $50 \%, 75 \%, 100 \%$. Samples were impregnated using different aqueous solutions for $24 \mathrm{hr}$ and then activated by varying activating temperatures from 300 to $600^{\circ} \mathrm{C}$ at various activation time periods such as $1 \mathrm{hr}, 2 \mathrm{hr}$, $3 \mathrm{hr}$ and $4 \mathrm{hr}$ (Miranda and Renita, 2008). The impregnated sample kept inside the static bed reactor was placed in an electrical furnace for pyrolysis. Nitrogen from gas cylinder was fed to the electrical furnace to maintain an inert medium. The activated carbon obtained after each experiment was washed repeatedly with double distilled water to remove ions. The 
washed sample was dried in an air oven at $110^{\circ} \mathrm{C} \pm 5^{\circ} \mathrm{C}$ for $24 \mathrm{hrs}$ and then kept in a desiccator. Furthermore, it was crushed using mesh of size 100, stored in polythene cover and kept in an air tight container for further experiments.

Characterization of mango seed coat activated carbon: lodine number was determined by standard test method ASTM (2006). Methylene blue number and methyl violet number were determined according to standard test method of BIS (1977).

Persent yield: It is a vital parameter in activated carbon preparation and was calculated by dividing mass of mango seed coat activated carbon after carbonization process and initial mass of mango seed coat taken and then was multiplied by 100 .

B.E.T. surface area : Internal surface areas of mango seed coat activated carbons were measured by Quanta chrome NOVA (4200) based on standard $\mathrm{N}_{2}$ adsorption data (at $-196^{\circ} \mathrm{C}$ or $77 \mathrm{~K}$ ). Surface area was calculated using Brunauer- Emmett -Teller equation over relative pressure (P/P0) of $0.05 \mathrm{~atm}$ to $0.3 \mathrm{~atm}$.

\section{Results and Discussion}

It is evident that use of $\mathrm{H}_{3} \mathrm{PO}_{4}$ as activating agent at $400^{\circ} \mathrm{C}$ at a higher iodine number produced the highest quality of activated carbon. Also, the impregnation volume percentage and time had significant effect on iodine number as shown in Fig. 1. Higher iodine number of $831 \mathrm{mg} \mathrm{g}^{-1}$ was observed when $\mathrm{H}_{3} \mathrm{PO}_{4}$ was used at $50 \%$ impregnation volume $400^{\circ} \mathrm{C}$ for $1 \mathrm{hr}$. This result agrees with the studies of activated carbon from rubber wood sawdust (Prakashkumar et al., 2005; Kalavathy et al., 2010), apricot stones (Soleimani and Kaghazchi, 2008) and sisal fiber (Senthilkumar et al., 2013). With $\mathrm{HNO}_{3}, \mathrm{KOH}, \mathrm{HCl}$ and $\mathrm{NaOH}$, activation temperatures did not have much influence on the iodine number. Furthermore, decrease in the iodine number indicates destruction and shrinkage of pores. Above $400^{\circ} \mathrm{C}$, iodine number decreased with all activating agents except for $\mathrm{ZnCl}$ and was maximum at $400^{\circ} \mathrm{C}$ with $\mathrm{H}_{3} \mathrm{PO}_{4}$ and $500^{\circ} \mathrm{C}$ with $\mathrm{ZnCl}_{2}$ i.e., $831 \mathrm{mg} \mathrm{g}^{-1}$ and $684 \mathrm{mg} \mathrm{g}^{-1}$, respectively. This indicates a damage to the structure of activated carbon in the form of collapse of the pore wall with increase in temperature above $400^{\circ} \mathrm{C}$ for $\mathrm{H}_{3} \mathrm{PO}_{4}$ and $500^{\circ} \mathrm{C}$ for $\mathrm{ZnCl}_{2}$.

Activating temperature of $400^{\circ} \mathrm{C}$ mainly influences methylene blue number for activating agents. $\mathrm{H}_{3} \mathrm{PO}_{4}$ and $\mathrm{KOH}$, compared to other activating agents. Additionally, Impregnation volume percentage and time also had significant effect on methylene blue number. Maximal methylene blue number observed were $130 \mathrm{mg} \mathrm{g}^{-1}$ and $212 \mathrm{mg} \mathrm{g}^{-1}$ with activating agents $\mathrm{KOH}$ and $\mathrm{H}_{3} \mathrm{PO}_{4}$, at $50 \%$ impregnation volume $400^{\circ} \mathrm{C}$ temperature for $1 \mathrm{hr}$ with $\mathrm{H}_{3} \mathrm{PO}_{4}$, having the highest methylene blue number compared to other activating agents as illustrated in Fig. 2. When $\mathrm{H}_{3} \mathrm{PO}_{4}$ reacts within the internal cellulose structure of mango seed coat, it is assumed to induce polymerization leading to an enhancement of pore volume, and thus global volume expansion favoring formation of mesopores (Olawale et al., 2015). The activating temperature increases methylene blue number, thus increasing the micropore structure and widening of mesopores. Moreover, above $400^{\circ} \mathrm{C}$ decrease in methylene blue number decreases with any chemical activating agent indicates that there is no new pore formation, with the only possibility being pore widening.

The quality of $\%$ yield was maximum for mango seed coat activated carbon at $49.06 \%$ and $41.09 \%$ with $\mathrm{H}_{3} \mathrm{PO}_{4}$ at impregnation volume of $50 \%$ for $1 \mathrm{hr}$ at $300^{\circ} \mathrm{C}$ and $400^{\circ} \mathrm{C}$, respectively, (Fig. 3). It is also evident that \% yield decreases with increasing activation temperature for various chemical activating agents. This result agrees with the studies of activated carbon from waste materials (Aajish and Thirumal, 2014) and groundnut foliage (Lakshmi et al., 2018). During the carbonation process, the lignocellulose in the mango seed coat reacts with phosphoric acid. Consequently, the acid first attacks hemicellulose and lignin as cellulose is more resistant to acid hydrolysis. These reactions are accompanied by further chemical transformations which include dehydration, degradation and condensation. As the acid concentration increases, aromatic condensation reactions also take place among the adjacent molecules which result in the formation of gaseous products from the hydro aromatic structure of carbonized char leading to decreased yield of carbon. The \% yield from $\mathrm{H}_{3} \mathrm{PO}_{4}$ is relatively higher than other activating agents, which indicates the ability of $\mathrm{H}_{3} \mathrm{PO}_{4}$ to retain carbon and to avoid the loss of volatile materials. In addition to that, $\mathrm{H}_{3} \mathrm{PO}_{4}$ activation promotes dehydration and redistribution of biopolymers and also favors the conversion of aliphatic compounds to aromatic, thus increasing the yield of activated carbon.

lodine number and methylene blue number value indicate the micropore and mesopore developed in the mango seed coat activated carbon during the activation process. Based on iodine number and methylene blue number, $400^{\circ} \mathrm{C}$ was selected as optimum activation temperature (Cheung et al., 2017) and the performance of selected activating agents was found in the order: $\mathrm{H}_{3} \mathrm{PO}_{4}>\mathrm{ZnCl}_{2}>\mathrm{KOH}>\mathrm{NaOH}>\mathrm{HCl}>\mathrm{HNO}_{3} . \mathrm{H}_{3} \mathrm{PO}_{4}$ has been widely used as an activating agent because of its tendency to create palpable surface area and better yield, which was also confirmed in this study.

The influence of $\mathrm{H}_{3} \mathrm{PO}_{4}$ at $400^{\circ} \mathrm{C}$ for $1 \mathrm{hr}$ at different impregnation volume percentage on mango seed coat has been shown in Fig. 4. Four different impregnation volumes of $25 \%$, $50 \%, 75 \%$ and $100 \%$ were used. The iodine number was maximum at $\mathrm{H}_{3} \mathrm{PO}_{4}$ impregnation volume of $75 \%$ i.e., $976 \mathrm{mg} \mathrm{g}^{-1}$ and methylene blue number at $\mathrm{H}_{3} \mathrm{PO}_{4}$ impregnation volume of $50 \%$ i.e., $212 \mathrm{mg} \mathrm{g}^{-1}$. Furthermore, iodine number increased as $\mathrm{H}_{3} \mathrm{PO}_{4}$ impregnation volume percentage increased from $25 \%$ to $75 \%$, after which there was a decrease in iodine number because activated carbon micropores decreased with increasing impregnation volume due to excessive carbon burn-off, collapse of pore walls and expansion of micropores to mesopores. Other than that, methylene blue number also increased with increase in 


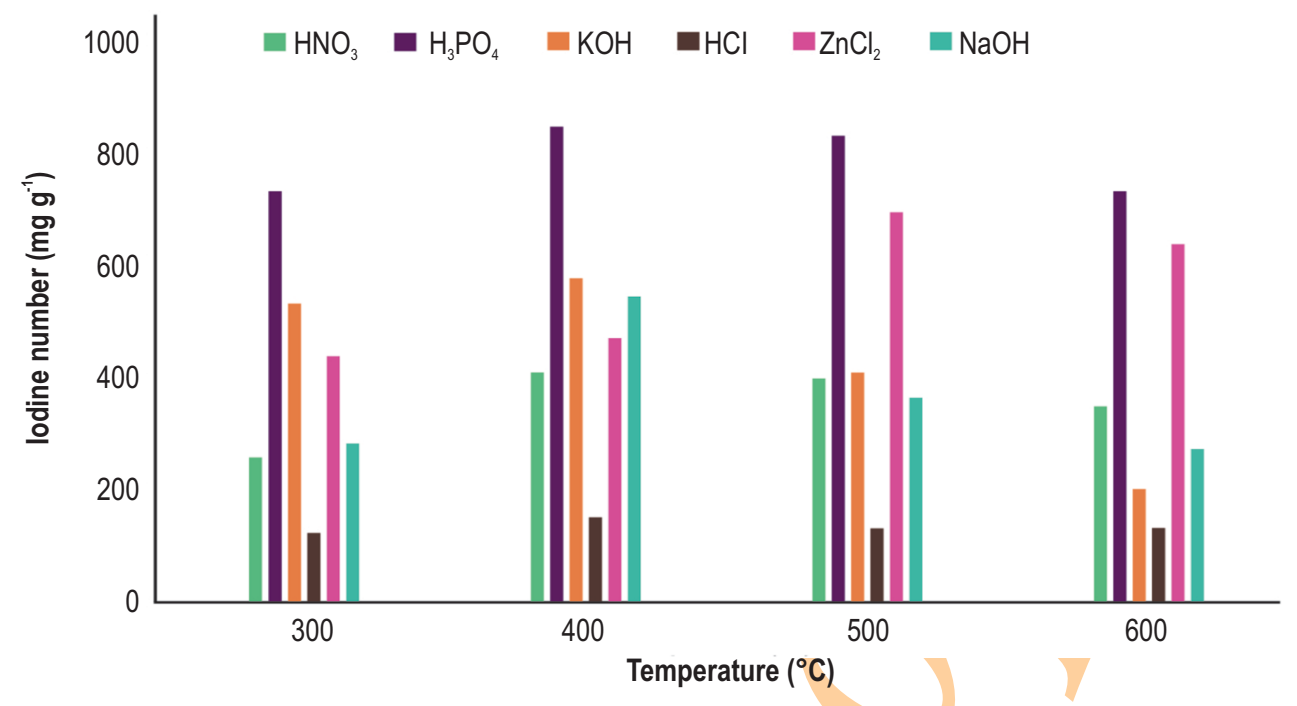

Fig. 1 : Effect of different activating temperatures $\left({ }^{\circ} \mathrm{C}\right)$ on raw mango seed coats using various activating agents and the corresponding lodine number $\left(\mathrm{mg} \mathrm{g}^{-1}\right)$ for mango seed coat activated carbon. Activating condition: Impregnation volume percentage : 50 ; Normality of activating agents: $1 \mathrm{~N}$; Activating temperature: $300^{\circ} \mathrm{C}, 400^{\circ} \mathrm{C}, 500^{\circ} \mathrm{C}, 600^{\circ} \mathrm{C}$; Activating time: $1 \mathrm{hr}$ and Activating agents: $\mathrm{HNO}_{3}, \mathrm{H}_{3} \mathrm{PO}_{4}, \mathrm{KOH}, \mathrm{HCl}, \mathrm{ZnCl}, \mathrm{NaOH}$.

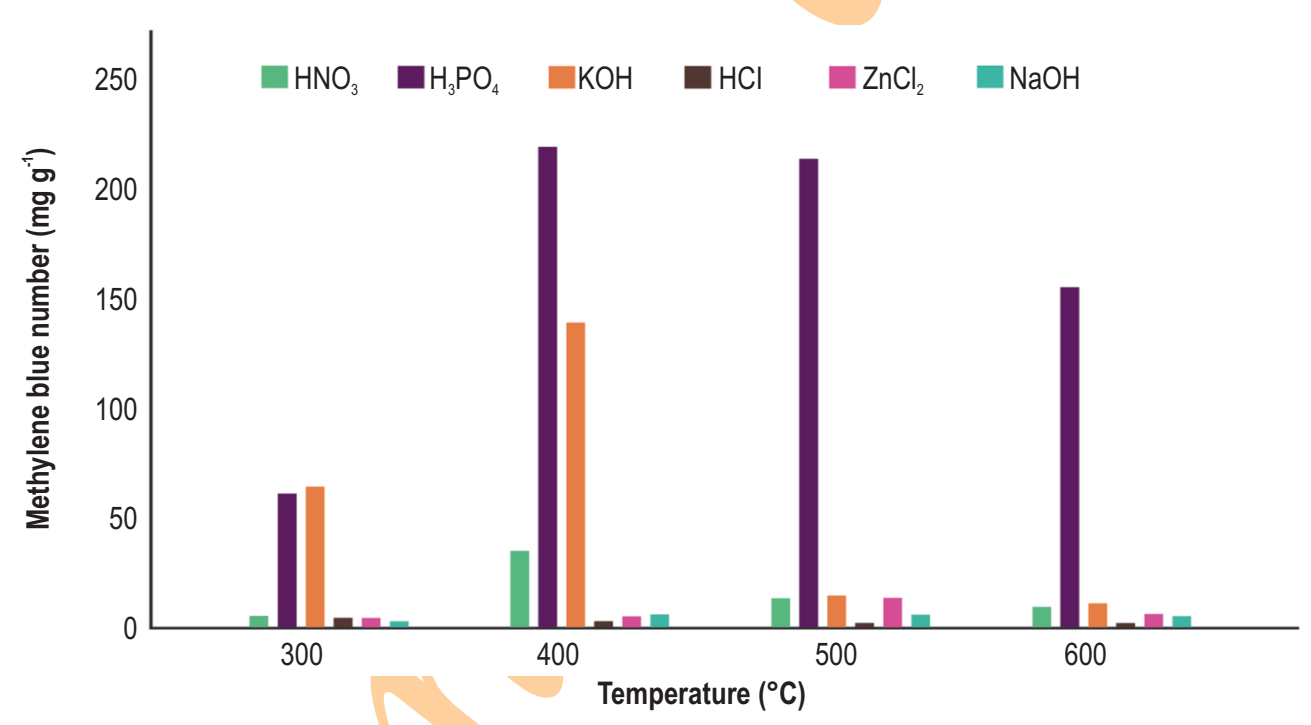

Fig. 2 : Effect of different activating temperatures $\left({ }^{\circ} \mathrm{C}\right)$ on raw mango seed coats using various activating agents and the corresponding Methylene blue number ( $\mathrm{mg} \mathrm{g}^{-1}$ ) for mango seed coat activated carbon. Activating condition: Impregnation volume percentage: 50 Normality of activating agents: $1 \mathrm{~N}$; Activating temperature: $300^{\circ} \mathrm{C}, 400^{\circ} \mathrm{C}, 500^{\circ} \mathrm{C}, 600^{\circ} \mathrm{C}$ Activating time: 1 hr and Activating agents: $\mathrm{HNO}_{3}, \mathrm{H}_{3} \mathrm{PO}_{4}, \mathrm{KOH}, \mathrm{HCl}, \mathrm{ZnCl}, \mathrm{NaOH}$.

$\mathrm{H}_{3} \mathrm{PO}_{4}$ impregnation volume percentage from $25 \%$ to $50 \%$. The decrease in this number may be attributed to new micropores being created inside the mesopore of mango seed coat activated carbon. Moreover, the \% yield increases with increased in $\mathrm{H}_{3} \mathrm{PO}_{4}$ impregnation volume from $25 \%$ to $50 \%$, after which it decreased. Yakout and El-Deen, (2016) observed that \% yield of carbon decreases as $\mathrm{H}_{3} \mathrm{PO}_{4}$ impregnation volume percentage increases. Excessive phosphoric acid promotes gasification of char and increase the total weight loss of carbon (Prahas et al., 2008). With increasing quantity of acid, it is expected that mass transfer within the substrate will be enhanced, leading to higher rate of reaction which manifests as reduced yield. Based on iodine number, $\mathrm{H}_{3} \mathrm{PO}_{4}$ impregnation volume of $75 \%$ was selected as impregnation volume percentage for mango seed coat activated carbon for varying activation hours. The effect of various activation time employed on $\mathrm{H}_{3} \mathrm{PO}_{4}$ at impregnation volume of $75 \%$ at $400^{\circ} \mathrm{C}$ on various parameters is shown in Fig. 5. Consequently, a high iodine number for activation time of $1 \mathrm{hr}$ was found i.e., $976 \mathrm{mg} \mathrm{g}^{-1}$ (Senthilkumar et al., 2013). Additionally, methyl blue number was highest at $173 \mathrm{mg} \mathrm{g}^{-1}$ for $2 \mathrm{hr}$ activation 
and $\%$ yield was maximum at $41.09 \%$ for $1 \mathrm{hr}$ activation. Alternatively, methyl violet number was highest at $110 \mathrm{mg} \mathrm{g}^{-1}$ for 4 $\mathrm{hr}$ activation time. As activation time increases, iodine number decreases (Ceyhan et al., 2013). Besides, residence time also influences the porosity development during the activation process. As it increases, the cleavage of oxygen groups are inhibited due to the presence of phosphate esters, and thus cyclization reaction does not occur (Rajagopal et al., 2006).
Influence of activation time on the development of micropore volume decreased by increasing activation time from $1 \mathrm{hr}$ to $2 \mathrm{hr}$, leading to rapid decrease in the iodine number. By increasing activation time, both methylene blue number and methyl violet number increased. Beyond activation time of $2 \mathrm{hr}$, there was no significant change in methylene blue number however, methyl violet number increased. Clearly, for the production of activated carbon, activation time of $2 \mathrm{hr}$ or more is

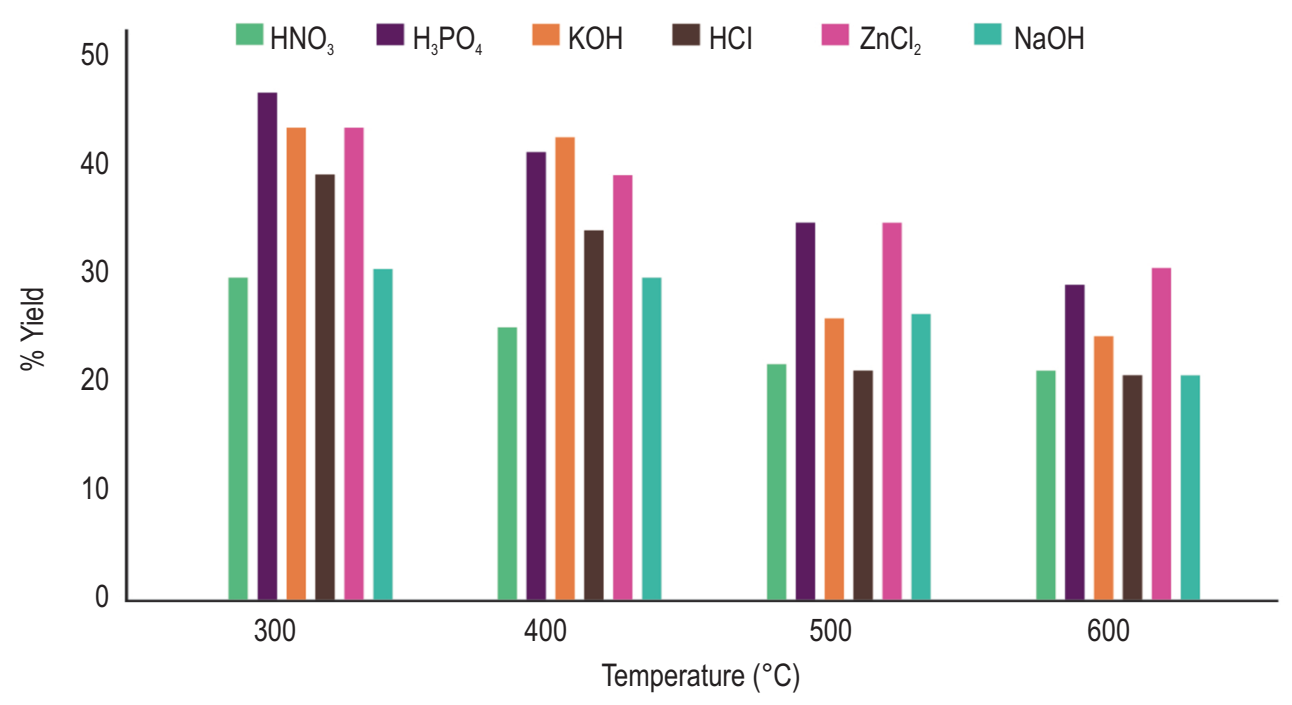

Fig. 3: Effect of different activating temperatures $\left({ }^{\circ} \mathrm{C}\right)$ on raw mango seed coats using various activating agents and the corresponding \% yield for mango seed coat activated carbon. Activating condition: Impregnation volume percentage: 50; Normality of activating agents: $1 \mathrm{~N}$; Activating temperature: $300^{\circ} \mathrm{C}, 400^{\circ} \mathrm{C}, 500^{\circ} \mathrm{C}, 600^{\circ} \mathrm{C}$ Activating time: 1 hr and Activating agents: $\mathrm{HNO}_{3}, \mathrm{H}_{3} \mathrm{PO}_{4}, \mathrm{KOH}, \mathrm{HCl}, \mathrm{ZnCl}, \mathrm{NaOH}$.

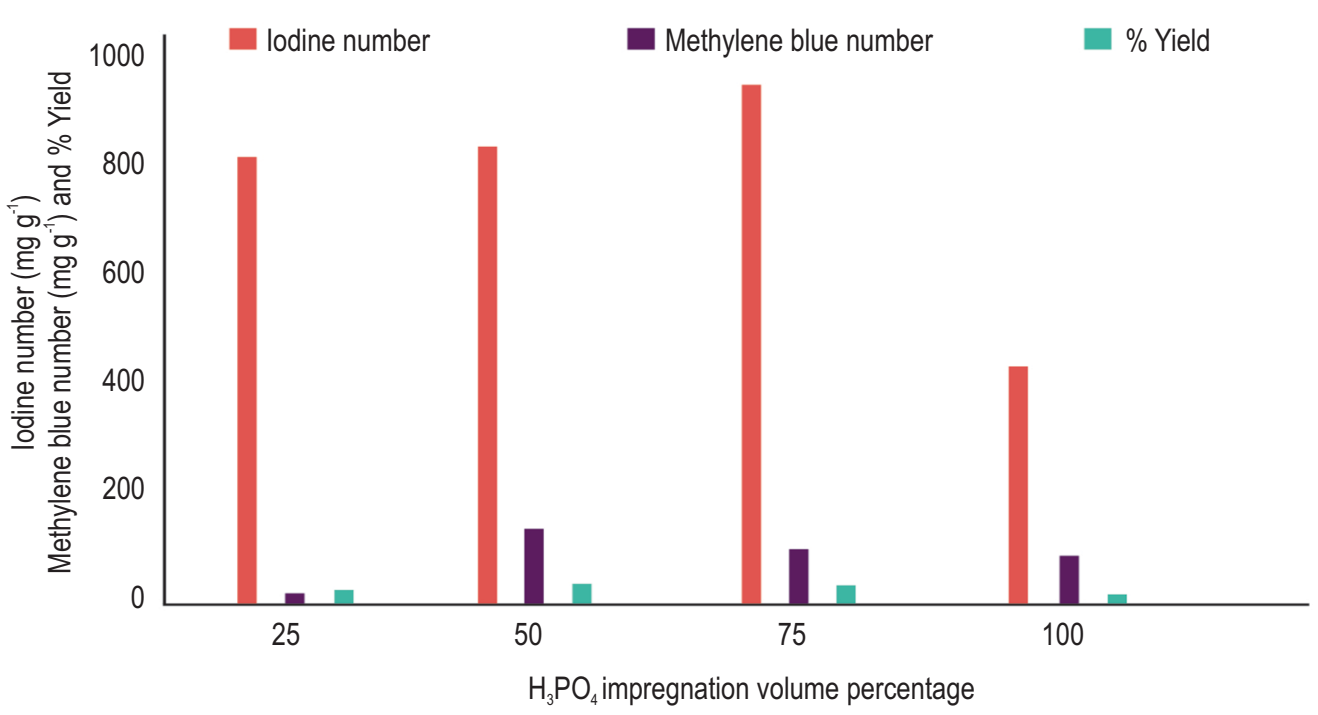

Fig. 4: Effect of various $\mathrm{H}_{3} \mathrm{PO}_{4}$ impregnation volume percentages on raw mango seed coat at $400^{\circ} \mathrm{C}$. Activating condition: $\mathrm{H}_{3} \mathrm{PO}_{4}$ Impregnation volume percentage: $25,50,75,100 ; \mathrm{H}_{3} \mathrm{PO}_{4}$ Normality: $1 \mathrm{~N}$ and Activating time: $1 \mathrm{hr}$. 


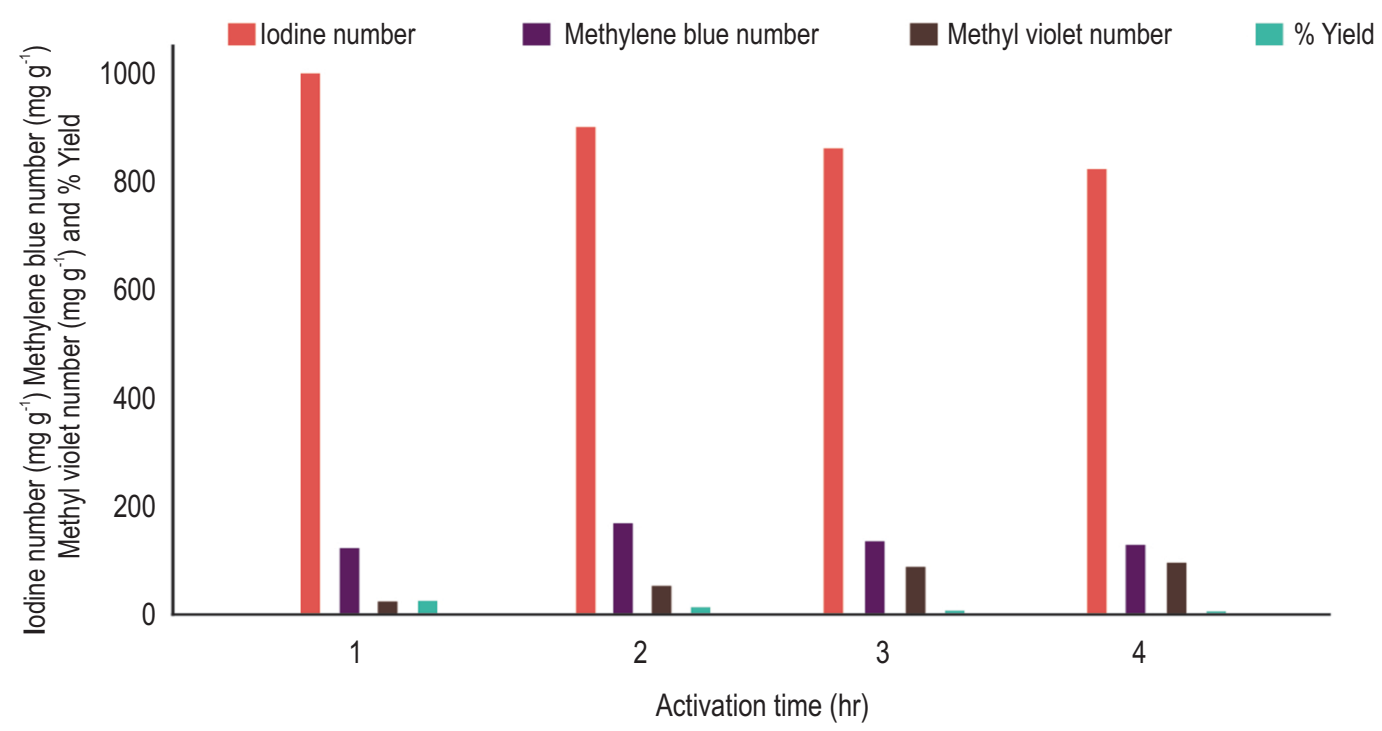

Fig. 5: Effect of various activating time (hrs) on mango seed coat $\mathrm{H}_{3} \mathrm{PO}_{4}$ impregnation volume of $75 \%$ at $400^{\circ} \mathrm{C}$. Activating condition: Activating temperature: $400^{\circ} \mathrm{C} ; \mathrm{H}_{3} \mathrm{PO}_{4}$; Normality: $1 \mathrm{~N}$ and Activating time: $1 \mathrm{hr}, 2 \mathrm{hr}, 3 \mathrm{hr}$ and $4 \mathrm{hr}$.

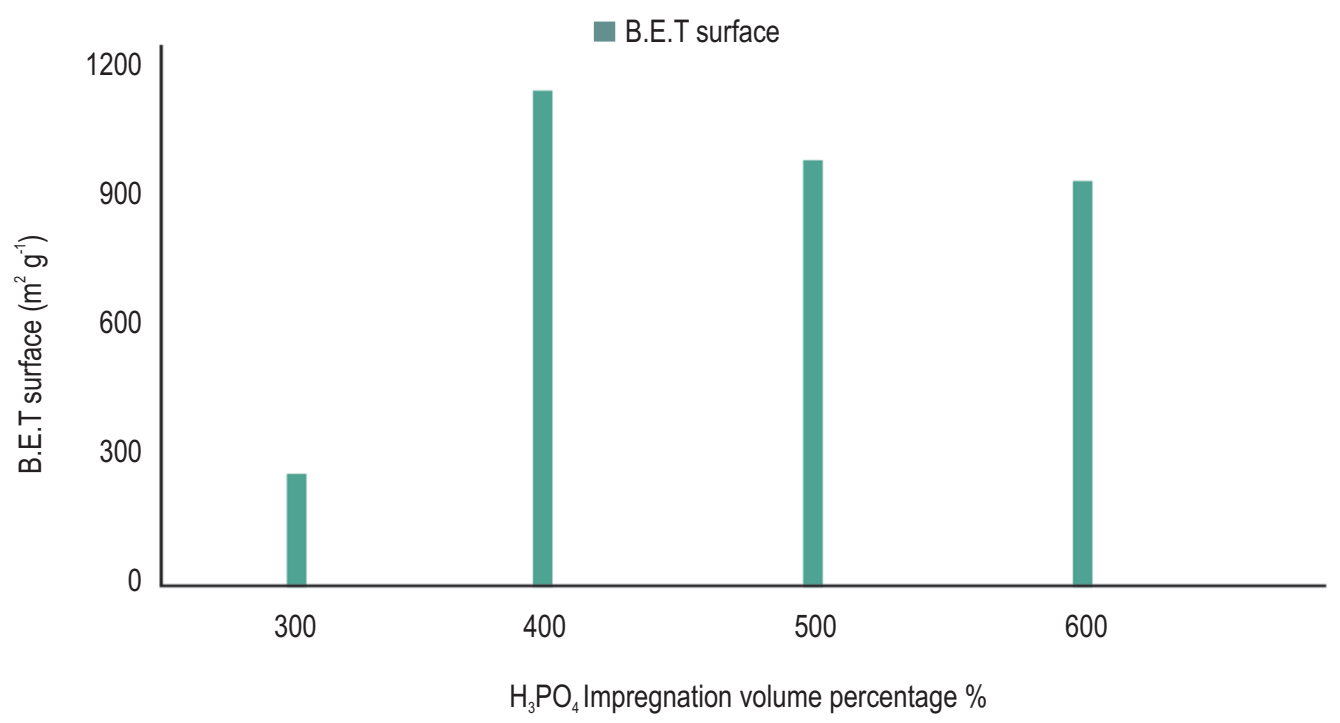

Fig. 6: Effect of different activating temperatures $\left({ }^{\circ} \mathrm{C}\right)$ on B.E.T surface area $\left(\mathrm{m}^{2} \mathrm{~g}^{-1}\right)$ of mango seed coat activated carbon. Activating condition: Activating Agent: $\mathrm{H}_{3} \mathrm{PO}_{4}$; Normality of activating agents: $1 \mathrm{~N}$; Impregnation volume percentage: $50 \%$ and Activating time: $1 \mathrm{hr}$.

not helpful for further pore development, though transformation of micropores to mesopores can be expected. This pore drilling dominant mechanism increases the diameter of pores only near their mouths (Herbert et al., 2008), thus, increasing activation time and decreasing \% yield (Aajish and Thirumal, 2014).

Based on methylene blue number, $\mathrm{H}_{3} \mathrm{PO}_{4}$ impregnation volume of $50 \%$ was selected as the optimum impregnation volume percentage for mango seed coat activated carbon and was further used to evaluate Brunauer-Emmett-Teller surface area. Fig. 6 shows the effect of various activating temperatures on the said surface area. It was highest at $1114 \mathrm{~m}^{2} \mathrm{~g}^{-1}$ with $\mathrm{H}_{3} \mathrm{PO}_{4}$ at $50 \%$ impregnation volume at $400^{\circ} \mathrm{C}$ for $1 \mathrm{hr}$, thus showing that the surface area adsorption capacity was high. Subsequently, as activating temperature increases from $300^{\circ} \mathrm{C}$ to $400^{\circ} \mathrm{C}$ (Dubey et al., 2009), the B.E.T surface area also increases accordingly after which it decreases gradually. This can be attributed to degradation of cell wall, causing larger pore size and less surface area above $400^{\circ} \mathrm{C}$ (Boonpoke, 2015). The mango seed coat activated carbon's adsorption capacity is 
based on its iodine number and methylene blue number. Gas adsorbing carbons usually have more micropores and liquid adsorbing carbons have significant number of mesopores due to larger size of liquid molecules (Wang et al., 2013). In the present study, mango seed coat activated carbon was used for the removal of gaseous as well as liquid pollutants.

The process conditions for removal of gaseous impurities were: Activating agent $\mathrm{H}_{3} \mathrm{PO}_{4}(1 \mathrm{~N})$, impregnation volume $75 \%$, activation time $1 \mathrm{hr}$, activating temperature $400^{\circ} \mathrm{C}$ : lodine number $976 \mathrm{mg} \mathrm{g}^{-1}$, Methylene blue number $153 \mathrm{mg} \mathrm{g}^{-1}$ and Methyl violet number $45 \mathrm{mg} \mathrm{g}^{-1}$. On the other hand, for removal of impurities from liquids process conditions were: Activating agent $\mathrm{H}_{3} \mathrm{PO}_{4}(1 \mathrm{~N})$, impregnation volume $50 \%$, activation time $1 \mathrm{hr}$, activating temperature $400^{\circ} \mathrm{C}$. lodine number $831 \mathrm{mg} \mathrm{g}^{-1}$, methylene blue number $212 \mathrm{mg} \mathrm{g}^{-1}$ and B.E.T. surface area $1114 \mathrm{~m}^{2} \mathrm{~g}^{-1}$, respectively. The commercial activated carbon (e-Merch India Ltd) had iodine number $834 \mathrm{mg} \mathrm{g}^{-1}$, methylene blue number $210 \mathrm{mg} \mathrm{g}^{-1}$, methyl violet number $150 \mathrm{mg} \mathrm{g}^{-1}$ (Rajgopal et al., 2006) and B.E.T. surface area $890.0479 \mathrm{~m}^{2} \mathrm{~g}^{-1}$ (Shalna and Yogamoorthi, 2015).

US Environmental Protection Agency has recommended activated carbon as one of the best dye removers (Karthikeyan et al., 2012). However, cost is the limiting factor for use of commercial activated carbon. From the above results, it can be concluded that the study of preparing activated carbon from mango seed coat produces good quality results as compared to commercial activated carbon. It can be used commercially for necessary applications. Thus, production of activated carbons with high surface area from mango seed coat (a waste material from mango pulp and fruit juice industries) is indeed important from economic and environmental aspects.

\section{Acknowledgments}

The author express heartfelt thanks to the Chemical Engineering Laboratory, Department of Petro-Chemical Technology, Anna University, Triuchirappali and also to the Management, Excel group of Institutions, Namakkal for the facilities provided during the study.

\section{References}

ASTM.: American Society for Testing and Materials (ASTM): Standard test method for determination of iodine number of activated carbon. ASTM D4607-94 (2006).

Abechi, S.E., C.E. Gimba, A. Uzairu and Y.A. Dallatu: Preparation and characterization of activated carbon from palm kernel shell by chemical activation. Res. J. Chemical Sci., 3, 54-61(2013).

Aajish, L.G. and J. Thirumal: Preparation and characterization of activated carbon derived from waste materials and its application in the removal of fluoride from ground water. IOSR-J. Environ. Sci. Toxicol. Food Technol., 8, 28-33 (2014).

Ahiduzzaman, M. and A.M.S. Islam : Evaluation of characteristics of activated carbon form rice husk impregnated with zinc chloride and phosphoric acid. Am. J. Physical Chemi., 5, 94-98 (2016).

Bureau of Indian Standard (BIS): Determination of decolorizing power.
IS: 877, 9-10(1977).

Boonpoke, A. : Study on preparation of water hyacinth - based activated carbon for pulp and paper mill waste water treatment. J. Environ. Biol., 36, 1143-1148 (2015).

Ceyhan, A.A., O. Sahin, O. Baytar and C. Saka: Surface and porous characterization of activated carbon prepared from pyrolysis of biomass by two-stage procedure at low activation temperature and it's the adsorption of iodine. J. Analytic. Appl. Pyrol., 104, 378-383 (2013).

Cheung, A.W.H., C.L.S. Chan, K.S.T. Lau, S.J. Allen and G.M. Kay: Production of high surface area-activated carbons from waste bamboo scaffolding. Hkie Transactions, 24, 133-140 (2017).

Dubey, S.P., K. Gopal and J.L. Bersillon: Utility of adsorbent in the purification of drinking water: A review of characterization, efficiency and safety evaluation of various adsorbents. J. Environ. Biol., 30, 327-332 (2009).

Daniel, S., P.S.S. Shabudeen and A. Basker: Studies on characterization and removal of methylene blue with Delonix regia plant litters activated. Carbon encapsulated nano metal oxide. J. Environ. Biol., 36, 933-940 (2015).

Elizalde-Gonzalez, M.P. and V. Henandez-Montoya: Characterization of mango pit as raw material in the preparation of activated carbon for wastewater treatment. Biochem. Engin. J., 36, 230-238 (2007).

Herbert, A. J., N. Gargieya, P.M. Sunil, B.G. Prakash Kumar and L.R. Miranda: Steam activated carbon preparation using HTFBR from biomass and its adsorption characteristics. Carbon Letters, 9, 203-209 (2008).

Hagemann, N.K. Spokas, S. Hans-Peter, R. Kagi, M.A. Bohler and T.D. Bucheli: Activated carbon, biochar and charcoal: Linkages and synergies across pyrogenic carbon's ABCs. Water, 10, 182-201 (2018).

Kostermans, A.J.G.H and J.M. Bombard: The Mangoes. $1^{\text {st }}$ Edn., Academic Press, London (1993).

Kumar, S., A. Gupta and J.P. Yadav: Removal of fluoride by thermally activated carbon prepared from neem (Azadirachta indica) and kikar (Acacia arabica) leaves. J. Environ. Biol., 29, 227-232 (2008).

Kalavathy, H.B. Karthi and L.R. Miranda: Removal and recovery of Ni and $\mathrm{Zn}$ from aqueous solution using activated carbon from Hevea brasiliensis: Batch and column studies. colloids Surface $B$ : Biointerfaces, 78, 291 - 302 (2010).

Kittiphoom, S.: Utilization of mango seed. Int. Food Res. J., 19, 1325 $1335(2012)$

Karthikeyan, S. and P. Sivakumar : The effect of activating agents on the activated carbon prepared from Feronia limonia (L) Swingle (wood apple) shell. J. Environ. Nanotechnol., 1, 5-12 (2012).

Koshle, S., S. Mahesh and S.N. Swamy: Isolation and identification of Trichoderma harzianum from ground water: An effective biosorbent for defluoridation of ground water. J. Environ. Biol., 37, 135-140 (2016).

Khairul, N.A., A. Fisal, H.S. Mohd, N. Khairunisa and M.A. Ahmad: Adsorption of chemically prepared Cocoa nibs based activated carbon onto methylene blue: Equilibrium and kinetic studies. Int. J. Petrochem. Res., 1, 15-18 (2017).

Lakshmi, D.V., L.A. Jegadeeswari, N. Arunodhaya, E.V. Kumar and N.N. Gandhi: Preparation and charactersiation of low cost adsorbent from groundnut foliage by chemical activation. J. Environ. Biol., 39, 400-405 (2018).

Miranda, L.R. and A.A. Renita: Manufacture of activated carbon from rubber wood for tailor made applications. Int. J. App. Bioengin., 2 , $21-24(2008)$

Moreno - Pirajan, J.C. and L. Giradio: Study of activated carbons by 
pyrolysis of Mangifera indica seed (Mango) in presence of sodium and potassium hydroxide. E-J. Chem., 9, 780-785 (2012).

Mise, S.R. and S.G. Jagannath: Adsorption studies of colour removed by activated carbon derived from Mangifera indica (Mango) seed shell. Int. J. Res. Engin. Technol., 2, 325-328 (2013).

Olawale, A.S., O. A.Ajayi, M.S. Olakunle, M.T. Ityokumbul and S.S. Adefila: Preparation of phosphoric acid activated carbon from Canarium schweinfurthii nutshell and its role in methylene blue adsorption. J. Chemical Engin. Mate. Sci., 6, 9-14 (2015).

Pearce, C.J., Lloyd and J.T. Guthrie: The removal of colour from textile wastewater using whole bacterial cells. Dyes and Pigments, 58,179-196 (2003).

Prakashkumar, B.G., L.R. Miranda and M.Velan: Adsorption of bismark brown dye on activated carbons prepared from rubber wood sawdust (Hevea brasiliensis) using different activation methods. J. Hazar. Mater., 26, $63-70$ (2005).

Prahas, D., Y. Kartika, N. Indraswati and S. Ismadji: Activated carbon from jackfruit peel waste by $\mathrm{H}_{3} \mathrm{PO}_{4}$ chemical activation: Pore structure and surface chemistry characterization. Chemical Eng. J., 140, 32-42 (2008).

Pandharipade, S.L., Y. Moharkar and R. Thakur: Synthesis of adsorbents from waste materials such as Ziziphus jujube seed and mango kernel. Int. J. Engine., 2,1337-1341(2012).

Rajgopal, S., T. Karthikeyan, B.G. Prakashkumar and L.R. Miranda: Utilization of fluidized bed reactor for the production of adsorbents in removal of malachite green. Chem. Engine. J.,116, 211 - 217 (2006).

Regunton, P.C.V., D.E.P. Sumalapao and N.R. Villarante: Biosorption of methylene blue from aqueous solution by coconut (Cocos nucifera) shell-derived activated carbon-chitosan composite. Oriental J. Chem., 34,115-124 (2018).
Soleimani, M., and T. Kaghazchi: Activated hard shell of apricot stones: A promising adsorbent in gold recovery. Chinese J. Chem. Engin., $16,112-118(2008)$.

Shalna, T. and A. Yogamoorthi: Preparation and characterization of activated carbon from used tea dust in comparison with commercial activated carbon. Int. J. Recent Scient. Res., 6, 2750 $-2755(2015)$.

Senthilkumar, T., R. Raghuraman and L.R. Miranda: Parameter optimization of activated carbon production from Agave sisalana and Punica granatum peel: Adsorbents for C.I. reactive orange 4 removal from aqueous solution. Clean-Soil Air Water, 41, 797 807 (2013).

Shahmoradi, M.H., B.A. Zade, A. Torabian and M.S. Salehi: Removal of nitrate from ground water using activated carbon prepared from rice husk and sludge of paper industry wastewater treatment. ARPNJ. Eng. Appl. Sci., 10, 7856-7863(2015).

Saravanan, N. and G. Rathika: Adsorption studies of methyl violet dye using biosorbents. Int. J. Chem. Tech. Res., 11, 84-94 (2018).

Sing, V.K., A.B. Soni and R.K. Sing: Comparative study of central composite and Box-Behnken design for the optimization of malachite green dye adsorption onto Sal seed activated char. J. Environ. Biol., 38, 849-858 (2017).

Timur,S., I.C. Kantarli, E. Ikizoglu and J.Yanik: Preparation of activated carbons from oreganum stalks by chemical activation. Energy and Fuels, 20, 2636-2641 (2006).

Wang,X., L. Danxi, L. Wei, J. Peng, Xia, L. Zhang, S. Guo and G. Chen: Optimization of meso pores activated carbon from coconut shell by chemical activation with phosphoric acid. Bio Resources, 8 , 6184$6195(2013)$.

Yakout, S.M. and G.S.EI-Deen: Characterization of activated carbon prepared by phosphoric acid activation of olive stones. Arabian J.Chem., 9, 1155-1162 (2016). 